\title{
ANALISIS PERMINTAAN PANGAN RUMAH TANGGA PENERIMA MANFAAT BANTUAN PANGAN NON TUNAI (BPNT) DI KOTA BOGOR
}

\author{
Anisah Nasution1), Bayu Krisnamurthi'2), dan Dwi Rachmina ${ }^{3)}$ \\ 1)Pelaksana Program Keluarga Harapan, Direktorat Jaminan Sosial Keluarga, Kementrian Sosial RI \\ Jl. Merdeka No. 142 Ciwaringin, Kota Bogor, Indonesia \\ 2,3)Departemen Agribisnis, Fakultas Ekonomi dan Manajemen, Institut Pertanian Bogor \\ Jl. Kamper Wing 4 Level 5 Kampus IPB Dramaga, Indonesia \\ 1)e-mail: anisanasti.an@gmail.com
}

(Diterima 16 Agustus 2019/ Disetujui 9 September 2019)

\begin{abstract}
Food is a basic need and access to food is a human rights that must be fulfilled. Meeting food needs is the main target of food policy carried out by the government, especially for the poor household. One of the government's policies in terms of food is Non-Cash Food Assistance (BPNT). The purpose of this study was to analysis the food demand for BPNT's beneficiary household and not receiving BPNT. This study used primary data on food consumption with the highest share of expenditure of poor households in Bogor City. Demand for food was estimated by LA-AIDS (Linear Approximation Almost Ideal Demand System) model. The results this study showed that there were significant differences in the average consumption of rice, non-rice and animal protein consumption between BPNT and non-BPNT households. The highest of food expenditure in both households was processed food and beverages. The BPNT dummy variable did not sign for a share of food expenditure. The result of the estimate also showed that rice, animal protein, vegetables, food and beverages and cigarettes are inelastic at their prices elasticity. All types of food studied were normal goods. Non-rice, vegetables and processed food and beverages were substitutes for rice in BPNT recipient households while in non-BPNT only processed food and beverages was substitutes for rice. The interesting thing in this research was that cigarettes become a complimentary item to all foods.
\end{abstract}

Keywords: demand for food, elasticity, LA-AIDS, share of food expenditure

\begin{abstract}
ABSTRAK
Pangan merupakan kebutuhan mendasar dan askes terhadap pangan adalah hak asasi yang layak dipenuhi. Pemenuhan kebutuhan pangan menjadi sasaran utama kebijakan pangan yang dilakukan oleh pemerintah, terutama bagi rumah tangga miskin. Salah satu kebijakan pemerintah dalam hal pangan adalah Bantuan Pangan Non Tunai (BPNT). Tujuan dari penelitian ini adalah untuk mengetahui permintaan pangan rumah tangga penerima manfaat BPNT dan rumah tangga bukan penerima BPNT. Penelitian ini menggunakan data primer konsumsi pangan dengan pangsa pengeluaran tertinggi rumah tangga miskin di Kota Bogor. Permintaan pangan dianalisis menggunakan model LA-AIDS (Almost Ideal Demand System). Hasil penelitian menunjukkan bahwa terdapat perbedaan yang signifikan pada ratarata konsumsi pangan beras, non beras dan protein hewani antara rumah tangga BPNT dan non BPNT. Pangsa pengeluaran pangan tertinggi pada kedua rumah tangga adalah makanan dan minuman jadi. Variabel kepesertaan BPNT tidak berpengaruh signifikan terhadap pangsa pengeluaran pangan rumah tangga. Beras, non beras, protein hewani, sayuran, makanan dan minuman jadi serta rokok inelastis terhadap harga sendiri. Semua jenis pangan yang diteliti merupakan barang normal. Non beras, sayuran dan makanan dan minuman jadi merupakan subsitusi bagi beras pada rumah tangga penerima BPNT sedangkan pada non BPNT hanya makanan dan minuman jadi yang merupakan substitusi bagi beras. Hal yang menarik dalam penelitian ini adalah rokok menjadi barang yang komplementer terhadap semua pangan.
\end{abstract}

Kata Kunci: elastisitas, permintaan pangan, LA-AIDS, pangsa pengeluaran pangan 


\section{PENDAHULUAN}

Pangan merupakan kebutuhan dasar bagi manusia yang harus dipenuhi karena merupakan sumber energi untuk mempertahankan hidup. Hak untuk memperoleh pangan merupakan salah satu hak asasi manusia, sebagaimana tercantum dalam pasal 27 UUD 1945. Oleh karenanya, sebagai kebutuhan dasar dan salah satu hak asasi manusia, pangan mempunyai arti penting bagi kehidupan suatu bangsa. Prabowo (2010) mengatakan bahwa pangan di Indonesia mempunyai kedudukan penting, terutama makanan pokok, karena menyangkut permasalahan politik, ekonomi, sosial dan budaya. Sejalan dengan itu sejarah perekonomian pangan Negara Kesatuan Republik Indonesia (NKRI) mencatat dengan jelas bahwa pemimpin negara ini secara konsisten meletakkan ekonomi pangan sebagai sesuatu hal yang sangat strategis (Suryana 2008).

Hubungan kemiskinan dan pemenuhan pangan sangat erat kaitannya. Hal tersebut karena besarnya proporsi pengeluaran untuk konsumsi pangan terhadap seluruh pengeluaran rumah tangga dapat dijadikan sebagai indikator kemiskinan. Makin tinggi kesejahteraan masyarakat suatu negara maka pangsa pengeluaran pangan penduduknya semakin kecil, demikian sebaliknya (Deaton \& Muellbauer, 1980). Kebijakan mengenai pangan dan kemiskinan juga sudah sejak lama dijalankan oleh pemerintah Indonesia. Hingga sekarang kebijakan pangan yang ditetapkan oleh pemerintah adalah program Bansos Rastra dan BPNT (Bantuan Pangan Non Tunai).

Program BPNT ini merupakan transformasi dari program subsidi Raskin/Rastra yang telah dijalankan sejak tahun 2017. Program ini awalnya menjadi pilot project di 44 Kota se Indonesia. Salah satunya adalah Kota Bogor. Penerima BPNT merupakan 25 persen rumah tangga termiskin di wilayahnya. Perbedaan program Raskin dan BPNT adalah terletak di fungsinya di mana raskin merupakan subsidi beras dengan harga murah dari pemerintah, sementara BPNT yaitu sebesar 25-34 persen dan MSC (2019) juga memaparkan hasil penelitiannya di 93 kabupaten/kota di 25 provinsi bahwa BPNT membantu 12-29 persen total pengeluaran makanan rumah tangga per bulan (atau mem- bantu 10-14 hari kebutuhan pangan). Hal tersebut menunjukkan bahwa BPNT memberikan pengaruh besar terhadap pengeluaran pangan KPM. Dengan kata lain, BPNT memberikan tambahan pendapatan kepada KPM adalah bantuan sosial yang diberikan oleh pemerintah dalam bentuk pangan beras dan atau telur (natura) sehingga KPM (Keluarga Penerima Manfaat) tidak lagi mengeluarkan uang untuk memperoleh bantuan pangan tersebut (TP3BSNT 2017).

Program Bantuan Pangan Non Tunai (BPNT) ini bertujuan mengurangi beban pengeluaran Keluarga Penerima Manfaat (KPM) melalui pemenuhan sebagian kebutuhan pangan, memberikan gizi yang seimbang kepada KPM (Keluarga Penerima Manfaat), meningkatkan ketepatan sasaran dan waktu penerimaan bantuan pangan serta mendorong kearah pembangunan yang berkelanjutan. Mekanisme penyaluran BPNT adalah setiap bulan KPM akan mendapatkan saldo sebesar Rp. 110000 yang ditransfer ke atm atau kartu KKS (Kartu Keluarga Sejahtera), kemudian setiap tanggal 25 (atau tanggal yang ditetapkan oleh E-Warong KUBE PKH atau agen Bank) KPM dapat membeli beras dan atau telur di E-Warong KUBE PKH dan agen yang telah ditetapkan sesuai wilayah tempat tinggal KPM (TP3BSNT 2017).

Dua hasil penelitian menunjukkan bahwa BPNT menjamin ketersediaan pangan sebagian dari beras yang dibutuhkan KPM. Rachman et al. (2018) menyatakan bahwa kontribusi BPNT dalam pemenuhan kebutuhan beras di lima kota Pendapatan rumah tangga sangat besar pengaruhnya terhadap tingkat konsumsi. Biasanya semakin tinggi pendapatan, tingkat konsumsi semakin tinggi. Karena tingkat pendapatan meningkat, kemampuan rumah tangga untuk membeli aneka kebutuhan konsumsi menjadi besar atau mungkin pola hidup menjadi semakin konsumtif (Rahardja dan Manurung 2008). BPNT memberikan tambahan pendapatan kepada KPM, yang diduga memengaruhi perilaku KPM dalam menentukan jenis pangan yang akan dikonsumsinya sehingga mengubah pola konsumsinya. Adanya perubahan pendapatan akan memberikan respons yang berbeda pada setiap rumah tangga dan berbeda pula pada setiap kelompok pangan yang akan dikonsumsi. Rumah tangga mis- 
kin di Kota Bogor memiliki pangsa pengeluaran untuk pangan yang cukup tinggi yaitu mencapai 62.87 persen dari total pendapatan (BPS Kota Bogor 2018). Hal ini berarti rumah tangga miskin di Kota Bogor sebagian besar mengalokasikan pendapatannya untuk pangan. Namun rumah tangga dengan pendapatan rendah tidak memiliki banyak pilihan untuk mengganti pola pangan mereka karena keterbatasan pendapatan (Norton et al. 2010).

Rumah tangga miskin memiliki pendapatan yang rendah, akibatnya daya beli nya juga rendah. Oleh karena itu rumah tangga miskin sangat memperhatikan harga dari pangan yang akan dikonsumsinya. Harga menjadi faktor yang memengaruhi permintaan rumah tangga. Selain mempertimbangkan harga pangan yang akan dikonsumsi, rumah tangga juga mempertimbangkan harga pangan lain yang saling berhubungan (Rahardja dan Manurung 2008).

Jumlah rumah tangga juga mempengaruhi jumlah konsumsi pangan rumah tangga. Semakin bertambah jumlah anggota keluarga maka permintaan terhadap pangan umumnya akan bertambah. Faktor lain yang diduga memengaruhi pola permintaan pangan rumah tangga miskin adalah kepesertaan BPNT. Diduga terdapat perbedaan pola permintaan pangan antara rumah tangga BPNT dan rumah tangga non BPNT. Hal ini karena KPM BPNT tidak lagi mengeluarkan uangnya untuk mendapatkan bantuan pangan berupa beras dan atau telur sedangkan rumah tangga non BPNT mengeluarkan uang untuk memperoleh beras dan atau telur.

Penelitian mengenai pola permintaan pangan sudah banyak dilakukan namun penelitian tentang perbedaan pola permintaan KPM BPNT dan non BPNT belum banyak dilakukan. Seberapa besar pengaruh perubahan pendapatan, harga dan variabel sosial demografi terhadap kuantitas dan kualitas konsumsi pangan perlu dikaji karena merupakan informasi penting bagi pemerintah dalam menetapkan kebijakan berkaitan dengan perbaikan konsumsi pangan masyarakat. Oleh karena itu, penelitian ini bertujuan menganalisis permintaan pangan rumah tangga penerima BPNT dan non BPNT dalam kaitannya dengan faktor harga dan pendapatan.

\section{METODE}

\section{LOKASI PENELITIAN}

Penelitian ini dilakukan di Kota Bogor. Penentuan lokasi penelitian dilakukan secara sengaja (purposive sampling). Hal ini berdasarkan pertimbangan bahwa Kota Bogor merupakan salah satu kota dari 44 kota seIndonesia yang menjadi pilot project program Bantuan Pangan Non Tunai (BPNT) sejak tahun 2017. Kota Bogor juga merupakan kota penerima terbanyak keempat di Jawa Barat setelah Kota Bekasi, Kota Bandung dan Kota Tasikmalaya. Waktu penelitian dilaksanakan pada bulan Maret-Agustus 2019.

\section{PENGUMPULAN DATA}

Data yang digunakan dalam penelitian ini merupakan data primer yang diperoleh dari wawancara kepada rumah tangga penerima BPNT dan non BPNT di Kota Bogor. Pengumpulan data primer dilakukan dengan metode recall konsumsi pangan seminggu terakhir terhadap pangan dengan pangsa pengeluaran tertinggi. Jenis pangan yang diteliti terdiri 6 kelompok pangan. Kelompok pangan tersebut adalah beras, non beras (tepung ketan, jagung, tepung terigu), protein hewani (ikan, daging, telur dan susu), sayuran, makanan dan minuman jadi serta rokok.

\section{PENENTUAN SAMPEL}

Metode penentuan sampel dalam penelitian ini adalah purposive sampling. Sampel terdiri dari dua kelompok rumah tangga miskin yaitu KPM BPNT selanjutnya disebut rumah tangga BPNT dan bukan penerima BPNT selanjutnya disebut non BPNT. Non BPNT ini dahulu merupakan rumah tangga penerima Raskin/Rastra. Data rumah tangga penerima BPNT tahun 2018 diperoleh Dinas Sosial Kota Bogor, sedangkan data non BPNT diperoleh dari data BDT 2015 Kota Bogor yang merupakan pusat data rumah tangga miskin. Jumlah sampel dalam penelitian ini adalah sebanyak 150 rumah tangga terdiri dari 110 rumah tangga BPNT dan 40 non BPNT.

\section{ANALISIS DATA}

Metode analisis data dalam penelitian ini menggunakan model Linear Approximation Almost Ideal Demand System ( LA-AIDS) yang dilakukan 
dengan pendekatan SUR (Seemingly Unrelated Regression). Model AIDS merupakan pengembangan dari kurva Engel dan fungsi permintaan tidak terkompensasi yang diturunkan dari teori maksimisasi ulititas (Deaton dan Muellbauer 1980). Pendekatan SUR dalam model LA-AIDS digunakan untuk melihat adanya hubungan eror dalam sistem persamaan, sehingga SUR diartikan sebagai regresi yang seolah-olah tidak berkaitan satu sama lain namun sebenarnya secara teori memiliki hubungan keterkaitan. Model LA-AIDS ini telah lama digunakan untuk meneliti tentang permintaan pangan seperti yang dilakukan oleh Deviana et al. (2014), Saidah (2014), Widianis (2014), Miranti et al. (2016), Yudistianto (2016), Mayasari et al. (2018), Wijayanti et al. (2019) Model dimodifikasi dengan melibatkan karakteristik demografi yaitu jumlah anggota rumah tangga dan kepesertaan BPNT. Model yang digunakan dalam penelitian ini adalah satu model yang digabung antara penerima BPNT dan non BPNT, namun untuk melihat perbedaan respons perilaku antara kedua rumah tangga maka dilihat dari nilai elastisitas masing-masing kelompok rumah tangga. Model yang digunakan adalah sebagai berikut:

$$
w_{i}=\alpha_{i}+\sum_{j=1}^{M} \gamma_{i j} \ln p_{j}+\beta_{j} \ln \frac{X}{P}+\eta_{i}, \ln A R T+\eta_{i} D+\varepsilon
$$

Keterangan:

$\begin{array}{ll}\text { wi } & : \text { pangsa pengeluaran pangan ke- } \mathrm{i} \\ \mathrm{i}, \mathrm{j} & : 1,2, \ldots 6 \text { (kelompok pangan) } \\ \alpha, \beta, \gamma, \eta & : \text { parameter model AIDS } \\ \mathrm{M} & : \text { jumlah kelompok pangan } \\ \mathrm{ln} \mathrm{pj} & \begin{array}{l}\text { : logaritma natural estimasi harga } \\ \text { komoditas ke-i }\end{array} \\ \mathrm{X} & : \text { total pengeluaran pangan } \\ \mathrm{P} & : \text { indeks harga stone, } \ln \mathrm{P}=\sum \mathrm{W}_{\mathrm{i}} \cdot \mathrm{ln} \mathrm{P}_{\mathrm{i}} \\ \mathrm{ln} \text { ART } & \begin{array}{l}\text { : logaritma natural jumlah anggota } \\ \text { keluarga }\end{array} \\ \mathrm{D} & \begin{array}{l}\text { dummy kepesertaan BPNT, BPNT }: 1, \\ \text { non BPNT:0 }\end{array} \\ \varepsilon & : \text { eror }\end{array}$

Ada beberapa persyaratan dasar yang harus dimiliki oleh sebuah model permintaan, yaitu retriksi-retriksi yang terdiri dari homogenity dan symmetri, sedangkan adding up sudah dipenuhi oleh model. Uji retriksi perlu dilakukan untuk menunjukkan efektifitas model yang digunakan.

\section{HASIL DAN PEMBAHASAN}

\section{PERMINTAAN PANGAN RUMAH TANGGA BPNT DAN NON BPNT}

Permintaan pangan rumah tangga BPNT dan non BPNT di Kota Bogor dapat dilihat dari nilai konsumsinya. Seperti yang ditunjukkan pada Tabel 1, konsumsi pangan rumah tangga BPNT maupun non BPNT menunjukkan bahwa pangsa pengeluaran dari yang terbesar adalah makanan minuman jadi, rokok, protein hewani, beras, sayuran dan non beras. Berdasarkan data BPS (2018) jumlah konsumsi beras kedua rumah tangga tersebut masih berada di bawah rata-rata konsumsi pangan beras nasional tahun 2018 yaitu 6,2 kg per kapita. Jika dilihat secara rinci pada kedua rumah tangga, pangsa pengeluaran beras lebih rendah dibanding dengan makanan dan minuman jadi. Hal ini senada dengan penelitian Mauludyani et al. (2008) bahwa pola konsumsi masyarakat telah berubah dari beras ke makanan dan minuman jadi. Fenomena ini merupakan efek dari perkembangan industri makanan dan minuman jadi, kemudahan akses dan kepaktisan dalam memperoleh makanan minuman jadi membuat masyarakat lebih menarik untuk mengkonsumsinya.

Selama program BPNT berjalan sejak tahun 2017, rumah tangga penerima BPNT hanya satu kali memperoleh bantuan berupa beras dan telur. Menurut informasi dari E-Warong dan agen bahwa penyaluran bantuan dengan produk telur mengalami banyak risiko, sehingga setiap bulan rumah tangga penerima BPNT di Kota Bogor hanya memperoleh beras sebanyak $9 \mathrm{~kg}$. Ratarata total konsumsi beras pada rumah tangga penerima BPNT adalah 28,15 kg, sehingga karena adanya BPNT rumah tangga hanya mengeluarkan pendapatnya untuk membeli beras sebanyak 19,15 kg per bulan. Hal ini berarti rumah tangga penerima BPNT dapat mengurangi beban pengeluaran untuk beras sebanyak 32 persen. Dengan demikian rumah tangga BPNT mendapatkan tambahan pendapatan yang diharapkan dapat dialokasikan untuk kelompok pangan lain sebagai tambahan bahan nutrisi. Namun, 
Tabel 1. Rata-Rata Konsumsi Pangan Rumah Tangga Penerima BPNT dan Non BPNT per Kapita Sebulan pada April 2019

\begin{tabular}{|c|c|c|c|c|c|c|c|}
\hline \multirow[b]{2}{*}{ Kelompok Pangan } & \multicolumn{3}{|c|}{ BPNT } & \multicolumn{3}{|c|}{ non BPNT } & \multirow[b]{2}{*}{$\begin{array}{c}\text { Uji } \\
\text { Beda }\end{array}$} \\
\hline & $\begin{array}{l}\text { Konsumsi } \\
\text { (Kg) }\end{array}$ & Pengeluaran & $\begin{array}{c}\text { Share } \\
\text { Pengeluaran } \\
(\%)\end{array}$ & $\begin{array}{c}\text { Konsumsi } \\
\text { (Kg) }\end{array}$ & Pengeluaran & $\begin{array}{c}\text { Share } \\
\text { Pengeluaran } \\
(\%)\end{array}$ & \\
\hline Beras & 5,49 & 62,953 & 15 & 6,08 & 68,422 & 13 & $0,01^{* *}$ \\
\hline Non beras & 0,69 & 6,702 & 2 & 0,57 & 5,553 & 1 & $0,01^{* *}$ \\
\hline Protein hewani & 2,68 & 69,160 & 16 & 2,65 & 74,339 & 14 & $0,01^{* *}$ \\
\hline Sayuran & 2,99 & 45,332 & 11 & 3,36 & 52,105 & 10 & 0,15 \\
\hline Mak/Min jadi & 17,04 & 161,985 & 38 & 26,13 & 237,769 & 44 & 0,28 \\
\hline Rokok* & 52,51 & 80,748 & 19 & 67,51 & 101,269 & 19 & 0,89 \\
\hline Total & & 426,879 & 100 & & 539,457 & 100 & \\
\hline
\end{tabular}

Keterangan: *) batang

berdasarkan Tabel 1 dapat diketahui dari nilai uji beda rata-rata konsumsi pangan menunjukkan bahwa kelompok pangan beras, non beras dan protein hewani lebih kecil dari alpa 0,05 yang menunjukkan bahwa terdapat perbedaan ratarata konsumsi pangan kelompok pangan tersebut pada taraf nyata 5 persen. Hal ini sesuai dengan dugaan awal bahwa dengan adanya BPNT rumah tangga memperoleh tambahan pendapatan dan mengalokasikannya untuk pangan lain yaitu untuk non beras dan protein hewani walaupun nilainya sangat kecil.

Pangsa pengeluaran rokok pada rumah tangga penerima BPNT dan non BPNT sama-sama berada pada posisi kedua dan nilainya juga sama yaitu 19 persen. Ironis sekali ketika rumah tangga miskin menjadikan rokok sebagai kebutuhan. Konsumsi rokok pada rumah tangga penerima BPNT dan non BPNT pada Tabel 1 dapat dikatakan cukup tinggi. Tingginya pangsa pengeluaran untuk rokok inilah yang menjadikan rokok dimasukan dalam perhitungan GKM (Garis Kemiskinan Makanan) oleh BPS.

\section{FAKTOR-FAKTOR YANG MEMPENGARUHI PERMINTAAN PANGAN}

Sistem persamaan dalam model LA-AIDS memiliki beberapa kendala-kendala atau retriksiretriksi yang harus dipenuhi agar diperoleh suatu model permintaan pangan ideal. Retriksi-retriksi tersebut adalah additivity, homegenity dan symmetry. Retriksi tersebut dapat diuji secara statistik. Berdasarkan hasil uji retristik, diperoleh hasil bahwa nilai uji $\mathrm{F}$ pada ketiga retriksi adalah 0,0001 . Hal ini menunjukkan bahwa retriksi terpenuhi sehingga model menghasilkan fungsi permintaan pangan yang sesuai dengan fungsi permintaan.

Berdasarkan hasil estimasi model LA-AIDS dengan pendekatan Seemingly Unrelated Regression (SUR) pada permintaan pangan rumah tangga penerima BPNT dan bukan penerima BPNT di Kota Bogor menunjukkan bahwa nilai $R$-squared berkisar antara 0,0415 hingga 0,6532 persen. Hal ini berarti bahwa variasi proporsi pengeluaran (budget share) dari kelompok pangan yang diteliti dapat dijelaskan oleh model sekitar 4-65 persen sedangkan sisanya dijelaskan oleh faktor-faktor lain diluar model. Rendahnya nilai $R$-squared tersebut karena data yang digunakan adalah data cross section yang me-miliki tingkat heterogenitas yang tinggi. Gujarati (2010) mengemukakan bahwa data cross section melibatkan beberapa observasi dan memeliki tingkat diversitas yang tinggi sehingga nilai $R$-squared rendah tidak merupakan masalah.

Berdasarkan Tabel 2 dapat diketahui bahwa hanya harga protein hewani, sayuran dan rokok yang memengaruhi pangsa pengeluarannya. Pangsa pengeluaran beras dipengaruhi signifikan oleh harga protein hewani, makanan dan minuman jadi, rokok, pendapatan dan jumlah anggota keluarga. Selanjutnya hal yang menarik terlihat dari pengaruh harga rokok, dimana harga rokok memengaruhi hampir seluruh pangsa pengeluaran pangan yang diteliti kecuali non beras dan sayuran.

Pendapatan yang masukkan dalam model LA-AIDS merupakan proyeksi dari pengeluaran pangan. Hasil estimasi model LA-AIDS menunjukkan bahwa pendapatan berpengaruh negatif pada pangsa pengeluaran kelompok pangan beras, 
Tabel 2. Faktor-Faktor yang Memengaruhi Pangsa Permintaan Pangan dengan Model LA-AIDS

\begin{tabular}{lrrrrrr}
\hline \multicolumn{1}{c}{ Parameter } & $\begin{array}{c}\text { Pangsa } \\
\text { Beras }\end{array}$ & $\begin{array}{c}\text { Pangsa } \\
\text { Non Beras }\end{array}$ & $\begin{array}{l}\text { Pangsa } \\
\text { Protein } \\
\text { hewani }\end{array}$ & $\begin{array}{c}\text { Pangsa } \\
\text { Sayuran }\end{array}$ & $\begin{array}{c}\text { Pangsa } \\
\text { Mak/Min } \\
\text { Jadi }\end{array}$ & $\begin{array}{c}\text { Pangsa } \\
\text { Rokok }\end{array}$ \\
\hline Konstanta & 0,6089 & $-0,0656$ & 0,0207 & $1,0548^{* * *}$ & $0,9103^{* * *}$ & $-0,9663^{* * *}$ \\
P beras & 0,0722 & $-0,0051$ & $-0,0494^{* * *}$ & 0,0131 & $-0,0201^{* *}$ & $-0,0445^{* *}$ \\
P non beras & $-0,0051$ & 0,0309 & $-0,0009$ & $-0,0028$ & $-0,0041^{*}$ & $-0,0109$ \\
P protein hewani & $-0,0494^{* * *}$ & $-0,0009$ & $0,1623^{* * *}$ & $-0,0024$ & $-0,0218^{*}$ & $-0,0844^{* * *}$ \\
P sayuran & 0,0131 & $-0,0028$ & $-0,0024$ & $-0,0684^{*}$ & $-0,0038$ & $-0,0083$ \\
P mak/min jadi & $-0,0201^{* *}$ & $-0,0041^{*}$ & $-0,0218^{*}$ & $-0,0038$ & $-0,0341$ & $0,0785^{* * *}$ \\
P rokok & $-0,0445^{* *}$ & $-0,0109$ & $-0,0844^{* * *}$ & $-0,0083$ & $0,0786^{* * *}$ & $0,1366^{* * *}$ \\
Pendapatan & $-0,0592^{* * *}$ & $-0,0029$ & $-0,0451^{* * *}$ & $-0,0529 * * *$ & $-0,0230$ & $0,1675^{* * *}$ \\
Jumlah ART & $0,0786^{* * *}$ & $0,0074^{*}$ & $0,0213^{*}$ & $-0,0155$ & $-0,0950^{* *}$ & $-0,0250$ \\
Dummy BPNT & $-0,0019$ & 0,0039 & 0,0223 & 0,0035 & $-0,0341$ & 0,0084 \\
R-square & 0,4377 & 0,1091 & 0,3517 & 0,3745 & 0,0415 & 0,6532 \\
\hline
\end{tabular}

Keterangan: ${ }^{*}$ ) signifikan $10 \%,{ }^{* *}$ ) signifikan $5 \%,{ }^{* * *}$ ) signifikan $1 \%$

protein hewani dan, sayuran sedangkan pada rokok berpengaruh positif.

Variabel sosiodemografi dimasukkan dalam model LA-AIDS dimaksudkan untuk menangkap alokasi pangsa pengeluaran konsumsi rumah tangga. Berdasarkan nilai koefisien hasil estimasi sistem persamaan LA-AIDS, tidak semua variabel jumlah anggota keluarga menunjukkan pengaruh dalam menentukan pangsa pengeluaran pangan rumah tangga miskin di Kota Bogor.

Jumlah anggota keluarga memiliki pengaruh yang signifikan positif terhadap pangsa pengeluaran beras pada taraf nyata 1 persen. Artinya pangsa pengeluaran beras akan meningkat seiring meningkatnya jumlah anggota rumah tangga, namun sebaliknya pada makanan dan minuman jadi memiliki pengaruh yang signifikan negatif pada taraf nyata 5 persen. Hal ini diduga karena makanan dan minuman jadi memiliki harga yang relatif lebih mahal sehingga rumah tangga lebih memilih mengurangi belanja makanan minuman jadi ketika anggota rumah tangga bertambah. Hal ini senada dengan penelitian Wijayanti (2019).
Variabel sosiodemografi lainnya adalah kepesertaan BPNT. Hasil estimasi model LA AIDS menunjukkan bahwa kepesertaan BPNT tidak memberikan pengaruh secara signifikan terhadap semua pangsa pengeluaran pangan rumah tangga BPNT di Kota Bogor. Hal ini berarti pangsa pengeluaran pangan rumah tangga BPNT dan non BPNT tidak terdapat perbedaan.

\section{PENGARUH PERUBAHAN HARGA DAN PENDAPATAN}

Tahap berikutnya adalah melihat seberapa besar respons perubahan konsumsi pangan dengan cara menghitung nilai elastisitas. Nilai elastisitas dapat dilihat dari nilai elastisitas harga sendiri (own price elasticity), elastisitas pendapatan (expenditure elasticity), dan elastisitas harga silang (cross elasticity). Elastisitas harga sendiri merupakan cara yang mudah untuk mengukur sejauh mana respons permintaan rumah tangga terhadap perubahan harga kelompok pangan itu sendiri. Pada Tabel 3 dapat diketahui bahwa besarnya elastisitas harga sendiri, semua jenis pangan bersifat inelastis

Tabel 3. Elastisitas Harga Sendiri Menurut Kelompok Pangan pada Rumah Tangga Penerima BPNT dan Non BPNT

\begin{tabular}{lrrr}
\hline Kelompok Makanan & Total & BPNT & Non BPNT \\
\hline Beras & $-0,151^{* * *}$ & $-0,449$ & 0,119 \\
Non Beras & 1,294 & 0,980 & 0,346 \\
Protein Hewani & $0,344^{* *}$ & $0,241^{*}$ & $0,789^{* *}$ \\
Sayuran & $-1,139^{* * *}$ & $-1,193^{* * *}$ & $-1,349^{* * *}$ \\
Makanan dan Minuman Jadi & $-1,028^{* * *}$ & $-1,031^{* * *}$ & $-1,081^{* * *}$ \\
Rokok & $-1,172^{* * *}$ & $-0,776^{* * *}$ & $-2,100^{* * *}$ \\
\hline Keterangan: ${ }^{*}$ ) signifikan $\left.10 \%,{ }^{* *}\right)$ signifikan $\left.5 \%,{ }^{* * *}\right)$ signifikan $1 \%$ & &
\end{tabular}


Tabel 4. Elastisitas Harga Silang Menurut Kelompok Pangan pada Rumah Tangga BPNT

\begin{tabular}{lrrrrrr}
\hline \multicolumn{1}{c}{$\begin{array}{c}\text { Kelompok } \\
\text { Makanan }\end{array}$} & Beras & $\begin{array}{c}\text { Pangan } \\
\text { pokok } \\
\text { non beras }\end{array}$ & $\begin{array}{l}\text { Protein } \\
\text { hewani }\end{array}$ & Sayuran & $\begin{array}{c}\text { Makanan } \\
\text { minuman } \\
\text { jadi }\end{array}$ & Rokok \\
\hline Beras & & 1,6556 & $-0,1244$ & $0,7973^{* *}$ & 0,0077 & $-1,1081^{* * *}$ \\
Pokok non beras & $0,5282^{* * *}$ & & 0,1492 & $0,2934^{* *}$ & 0,0509 & $-0,8128^{* * *}$ \\
Protein hewani & 0,0854 & $-0,0379$ & & $0,3829^{* * *}$ & 0,0074 & $-0,9232^{* * *}$ \\
Sayuran & $0,6159^{* * *}$ & $-0,9913$ & 0,1153 & & 0,0530 & $-0,3854^{* *}$ \\
Mak-min jadi & $0,2603^{* * *}$ & $-0,0166$ & 0,0516 & $0,4407^{* * *}$ & & $-0,7757^{* * *}$ \\
Rokok & 0,0651 & 0,3479 & $-0,3578^{* *}$ & 0,3113 & 0,2779 & \\
\hline Keterangan: ${ }^{*}$ ) signifikan $10 \%,{ }^{* *}$ ) signifikan $5 \%^{* * *}$ signifikan $1 \%$ & & &
\end{tabular}

karena memiliki nilai elastisitas kurang dari 1 kecuali pangan non beras yang bersifat elastis. Namun jika dilihat secara terpisah, baik rumah tangga penerima BPNT maupun non BPNT semua kelompok pangan bersifat inelastis.

Berdasarkan Tabel 3 juga dapat dilihat bahwa semua kelompok pangan yang diteliti, rumah tangga non BPNT lebih sensitif terhadap perubahan harga dibandingkan rumah tangga penerima BPNT, kecuali pada pangan non beras. Hal yang menarik pada nilai elastisitas sendiri yaitu pada nilai elastisitas rokok non BPNT, bernilai lebih dari satu artinya kenaikan harga rokok sangat memberikan respons yang tinggi dalam penurunan konsumsi rokok rumah tangga.

Nilai elastisitas sendiri ada yang bertanda negatif dan bertanda positif. Nilai elastisitas harga sendiri yang negatif tersebut mengindikasikan bahwa bila terjadi kenaikan harga pada kelompok pangan tersebut maka permintaan terhadap pangan tersebut akan cenderung menurun. Fakta ini menunjukkan konsistensi dengan teori permintaan (Nicholson 2005). Namun terdapat nilai elastisitas sendiri yang bernilai positif dimana ketika harga pangan tersebut naik maka permintaan terhadap pangan tersebut juga naik. Hal ini terjadi karena efek pendapatan lebih besar daripada efek substitusi pada pangan tersebut (Hanafie 2010). Sehingga menurut preferensi rumah tangga miskin baik penerima BPNT maupun bukan penerima BPNT di Kota Bogor, protein hewani merupakan barang giffen. Barang dikatakan barang giffen hanya berlaku pada kelompok masyarakat tertentu, biasanya golongan pendapatan rendah.

Respons kenaikan harga pada suatu kelompok pangan tidak hanya berdampak pada kelompok pangan tersebut namun juga dapat memengaruhi perubahan permintaan pada kelompok pangan lainnya. Hal ini sebagaimana disebutkan dalam hukum permintaan bahwa terdapat dua hubungan yang dapat terjadi atas perubahan harga pada komoditas lain, yaitu hubungan substitusi dan hubungan komplementer. Nilai elastisitas silang dapat ditunjukkan pada Tabel 4 dan Tabel 5. Berdasarkan nilai elastisitas silang dapat diketahui bahwa pada rumah tangga penerima BPNT, beras memiliki hubungan substitusi dengan kelompok pangan non beras, sayuran dan makanan dan minuman jadi. Sementara rokok memiliki hubungan yang komplementer dengan semua jenis pangan.

Pada rumah tangga non BPNT, nilai elastitas silang menunjukkan bahwa beras hanya

Tabel 5. Elastisitas Harga Silang Kelompok Pangan pada Rumah Tangga Non BPNT

\begin{tabular}{|c|c|c|c|c|c|c|}
\hline $\begin{array}{c}\text { Kelompok } \\
\text { Makanan }\end{array}$ & Beras & $\begin{array}{c}\text { Pangan } \\
\text { pokok } \\
\text { non beras }\end{array}$ & $\begin{array}{l}\text { Protein } \\
\text { hewani }\end{array}$ & Sayuran & $\begin{array}{c}\text { Makanan } \\
\text { minuman } \\
\text { jadi }\end{array}$ & Rokok \\
\hline Beras & & $-3,3217$ & 0,4196 & $-0,2264$ & 0,0061 & $-1,1479 * * *$ \\
\hline Pokok non beras & 0,0560 & & $0,7233^{* *}$ & $0,6431^{* * *}$ & 0,0207 & $-1,1513^{* * *}$ \\
\hline Protein hewani & 0,1332 & $1,9479 *$ & & $0,6204^{* *}$ & $-0,0397$ & $-1,7353^{* * *}$ \\
\hline Sayuran & $-0,1789$ & 2,6913 & $0,7594^{* * *}$ & & 0,0402 & $-0,8839 * * *$ \\
\hline Mak-min jadi & $0,2763^{* *}$ & 0,3046 & $0,4168^{* *}$ & $0,4977^{* * *}$ & & $-0,6187^{* * *}$ \\
\hline Rokok & 0,3589 & 0,7314 & $-0,1141$ & $0,9089 * *$ & 0,2497 & \\
\hline
\end{tabular}


memiliki hubungan substitusi pada makanan dan minuman jadi. Sementara untuk rokok, pada rumah tangga non BPNT memiliki fenomena yang sama dengan rumah tangga BPNT yaitu dimana rokok memiliki hubungan yang komplementer dengan semua jenis pangan. Hal menarik dari nilai elastisitas silang pada rokok baik pada penerima BPNT dan non BPNT yaitu semua nilai elastisitas bernilai negatif. Hal ini menunjukkan bahwa ketika harga rokok naik maka rumah tangga akan menurunkan pangsa permintaannya terhadap semua jenis pangan. Penelitian Yusdiyanto (2016) menguatkan bahwa konsumsi rumah tangga miskin terhadap rokok cukup tinggi dan rokok memiliki hubungan komplementer dengan beras dan pangan lainnya.

Nilai elastisitas pendapatan (didekati dengan pengeluaran) dapat mencerminkan sifat suatu barang apakah termasuk barang normal (pokok), inferior atau mewah. Berdasarkan Tabel 6 dapat diketahui bahwa secara total, semua jenis pangan termasuk barang normal. Namun khusus pada rokok, rokok merupakan barang normal yang termasuk barang mewah karena memiliki elastisitas lebih besar dari 1. Artinya ketika pendapatan naik 10 persen maka rumah tangga akan meningkatkan permintaannya terhadap rokok sebesar 19,30 persen. Ironisnya peningkatan konsumsi rokok dilakukan oleh rumah tangga miskin meskipun berbahaya bagi kesehatan. Hal ini senada dengan penelitian Widianis (2014) dan Yusdianto (2016) bahwa elastisitas pendapatan pada rokok lebih dari 1.

Jika dilihat secara terpisah antara rumah tangga penerima BPNT dan non BPNT, semua kelompok pangan yang diteliti termasuk barang normal. Namun pada rumah tangga non BPNT nilai elastisitas pendapatan beras dan non beras tidak berpengaruh signifikan sehingga nilai elastisitasnya dianggap nol atau disebut inelastis sempurna. Artinya ketika elastisitas pendapatan nol yaitu ketika pendapatan naik maka tidak ada pengaruhnya terhadap jumlah permintaan beras dan non beras pada rumah tangga non BPNT. Pada rumah tangga penerima BPNT kelompok pangan protein hewani lebih elastis daripada rumah tangga non BPNT, namun pada rumah tangga non BPNT kelompok pangan sayuran, makanan dan minuman jadi dan rokok lebih elastis daripada rumah tangga penerima BPNT. Nilai elastisitas pendapatan pada rokok di kedua kelompok rumah tangga bernilai lebih dari satu. Hal ini menandakan bahwa rokok merupakan barang normal tetapi bersifat mewah. Pada rumah tangga non BPNT nilai elastisitas pendapatan pada rokok cukup tinggi yaitu 2,145. Artinya Ketika pendapatan naik 1 persen permintaan terhadap rokok meningkat sebesar 2,145 persen.

\section{SIMPULAN DAN SARAN}

\section{SIMPULAN}

1. Terdapat perbedaan rata-rata konsumsi pangan beras, non beras dan protein hewani antara rumah tangga penerima BPNT dan non BPNT, namun pangsa pengeluaran pangannya memiliki pola yang sama, yaitu mulai dari yang tertinggi makanan dan minuman jadi rokok, protein hewani, beras, sayuran dan non beras.

2. Harga protein hewani, sayuran dan rokok memengaruhi pangsa pengeluaran pangannya sendiri. Pendapatan hanya berpengaruh signifikan pada pangsa pengeluaran beras, protein, sayuran dan rokok. Jumlah rumah tangga hanya signifikan terhadap pangsa pengeluaran beras, non beras protein hewani, dan makanan minuman jadi. Kepesertaan BPNT tidak memberikan pengaruh pada

\section{Tabel 6. Elastisitas Pendapatan Menurut Kelompok Pangan pada Rumah Tangga Penerima} BPNT dan Non BPNT

\begin{tabular}{lrrr}
\hline Kelompok Makanan & Total & BPNT & Non BPNT \\
\hline Beras & $0,618^{* * *}$ & $0,609^{* * *}$ & 0,637 \\
Non Beras & $0,805^{* * *}$ & $0,699^{* * *}$ & 0,149 \\
Protein Hewani & $0,708^{* * *}$ & $0,816^{* * *}$ & $0,356^{* *}$ \\
Sayuran & $0,528^{* * *}$ & $0,521^{* * *}$ & $0,531^{* * *}$ \\
Makanan dan Minuman Jadi & $0,940^{* * *}$ & $0,935^{* * *}$ & $0,967^{* * *}$ \\
Rokok & $1,930^{* * *}$ & $1,817^{* * *}$ & $2,145^{* * *}$ \\
\hline Keterangan: ${ }^{* *}$ signifikan $10 \%,{ }^{* *}$ ) signifikan $\left.5 \%,{ }^{* * *}\right)$ signifikan 1\% &
\end{tabular}


semua pangsa pengeluran pangan rumah tangga miskin di Kota Bogor.

3. Berdasarkan elastisitas harga sendiri semua kelompok pangan bersifat inelastis pada rumah tangga BPNT dan non BPNT. Berdasarkan elastisitas harga silang pada rumah tangga penerima BPNT, kelompok pangan non beras, sayuran dan makanan minuman jadi merupakan substitusi dengan beras, sedangkan pada rumah tangga non BPNT, kelompok makanan dan minuman jadi merupakan substitusi bagi beras. Semua jenis pangan yang diteliti merupakan barang normal.

\section{SARAN}

1. Program BPNT perlu dikaji lagi oleh pemerintah karena tidak memberikan pengaruh signifikan pada pengeluaran pangan rumah tangga miskin.

2. Pemerintah pusat dan daerah perlu memperhatikan sinergi antara program bantuan pangan dengan program pengurangan konsumsi rokok pada rumah tangga miskin, karena hasil penelitian menunjukkan bahwa peningkatan pendapatan rumah tangga miskin dapat mengakibatkan peningkatan konsumsi rokok.

3. Pada penelitian selanjutnya perlu diketahui jumlah pendapatan rumah tangga.

\section{DAFTAR PUSTAKA}

[BPS] Badan Pusat Statistik Kota Bogor. 2018. Statistik Kesejahteraan Kota Bogor. Bogor (ID): BPS Kota Bogor.

[BPS] Badan Pusat Statistik. 2018. Konsumsi Beras Nasional 2018. Jakarta (ID): BPS.

[MSC] Microsave Consulting. 2019. Evaluasi operasional BPNT. Jakarta (ID): Microsave Consulting.

[TP3BSNT] Tim Pengendali Pelaksanaan Penyaluran Bantuan Sosial Secara Non Tunai. 2017. Pedoman Umum Bantuan Pangan Non Tunai. Jakarta (ID): TP3BSNT.
Deaton A dan Muellbauer. 1980. Price elasticities from survey data extensions and Indonesian results. Journal of Econometrics. 44: 281-309.

Deviana I, Kusrini N, Suyatno A. 2014. Analisis permintaan rumah tangga terhadap beras produksi Kabupaten Kubu Raya.Jurnal Social Economic of Agriculture. 3 (2).

Gujarati DN. 2010. Dasar-Dasar Ekonometrika Buku I. Jakarta (ID): Penerbit Salemba.

Hanafie R. 2010. Pengantar Ekonomi Pertanian. Yogyakarta (ID): Penerbit ANDI.

Mauludyani AVR, Martianto D, Baliwati YF. 2008. Pola konsumsi dan permintaan pangan pokok berdasarkan analisis data susenas 2005. Jurnal Gizi dan Pangan. 3(2)-101-117.

Mayasari D, Noor I, Satria D. 2018. Analisis pola konsumsi pangan rumahtangga miskin di Provinsi Jawa Timur. Jurnal Ilmu Ekonomi Pembangunan 1(18).

Miranti A, Syaukat Y, Harianto. 2016. Pola konsumsi rumah tangga di Provinsi Jawa Barat. Jurnal Agro Ekonomi. 34(1):67-80. doi:10.21082/jae.v34n1.2016.67-80.

Nicholson W. 2005. Mikroekonomi Intermediate dan Aplikasinya Edisi Delapan. Jakarta (ID): Erlangga.

Norton GW, Alwang J, Master WA. 2010. Economic of Agricultural Development. New York (US): Routledge.

Prabowo R. 2010. Kebijakan pemerintah dalam mewujudkan ketahanan pangan di Indonesia. Mediaagro. 6(2):62-73.

Rachman B, Agustian A, Wahyudi. 2018. Efektivitas dan perspektif pelaksanaan program beras sejahtera (rastra) dan bantuan pangan non tunai (BPNT). Analisis Kebijakan Pertanian. 16(1):118.doi:http://dx.doi.org/10.21082/akp.v16 n1.2018. 1-18.

Rahardja P dan Manurung M. 2008. Pengantar Ilmu Ekonomi Edisi Ketiga. Jakarta ID): Lembaga Penerbit Fakultas Ekonomi Universitas Indonesia.

Saidah N. 2014. Dampak kebijakan raskin terhadap pola konsumsi pangan pokok lokal 
di Papua [tesis]. Bogor (ID): Institut Pertanian Bogor.

Suryana A. 2008. Menelisik ketahanan pangan, kebijakan pangan dan swasembada beras. Pengembangan Inovasi Pertanian. 1(1):1-16.

Tengah [tesis]. Bogor (ID): Institut Pertanian Bogor.

Widianis D. 2014. Pola konsumsi pangan rumah tangga miskin di Provinsi Nusa Tenggara Timur [tesis]. Bogor (ID): Institut Pertanian Bogor.

Wijayanti PD. 2019. Permintaan pangan sumber karbohidrat di Indonesia. Analisis Kebijakan Pertanian. 1(17):13-25.

Yusdiyanto S. 2016. Pola konsumsi pangan ru mah tangga miskin di Provinsi Sulawesi Tengah [tesis]. Bogor (ID): Institut Pertanian Bogor 